\title{
Ergonomics analysis of gunner station of armoured combat vehicle (ACV)- Tank T 90S with special reference to seat, visual sighting system and musculoskeletal discomfort: A pilot study
}

\author{
Pankaj Kumar Sinha', Madhusudan Pal ${ }^{2}$, Sunil Chandel ${ }^{3}$ \\ ${ }^{1}$ Department of Applied Mathematics, Defence Institute of Advance Technology (DIAT), Defence Research and \\ Development Organisation (DRDO), Girinagar, Pune-25, Maharashtra, India, ${ }^{2}$ Scientist F \& Addl. Director ${ }^{2}$ Defence \\ Institute of Physiology and Allied Sciences (DIPAS), Defence Research and Development Organisation (DRDO), \\ Lucknow Road, Delhi -110054, India, ${ }^{3}$ Department of Mechanical Engineering, Defence Institute of Advance \\ Technology(DIAT), Defence Research and Development Organisation (DRDO), Girinagar, Pune-25, Maharashtra, India
}

Background: A combat vehicle is a tracked/wheeled land or amphibious vehicle, with or without armour or armament, designed for specific functions in combat or battle. It is an integrated mobile weapon platform comprising of multiple workstations having many equipment, switches, control and displays.Effectiveness of Combat vehicle and efficiency of crew in battle field depends upon the optimum design and placement of control and displays and workstation. Till date ergonomics studies on combat vehicle are limited and less reported. Aims and Objective: Present study was undertaken to investigate the gunner station of the combat vehicles (Tank T90 S) in special reference to seat and sighting system with respect to anthropometric dimensions of the crew members, in order to find out constraints, design limitations and mismatch in the existing vehicles; and the biomechanical responses (force and angles), comfort and discomfort during the vehicle operation. Materials and Methods: Ninety (90) healthy male gunners with mean age $35.2 \pm 8.5$ years, stature $172.6 \pm 7.5 \mathrm{~cm}$ and weight $72.4 \pm 7.2 \mathrm{~kg}$ volunteered for the study. Anthropometric details of gunner crew, gunner seat dimension, sighting system, biomechanical response during operation, comfort and discomfort analysis were also studied. Results: Gunner station sighting control handle is located below the recommended optimum vortex angle of $\pm 15^{\circ}$ from normal line of sight in vertical and horizontal plane. Hand grip strength decreased with increasing operation time. Reduction in grip strength of the gunner may tend to produce lag and delay of movement of barrel and swiftness of gunner may also get compromised. Seat was not designed as per anthropometric dimensions of crew members. Conclusion: Present study clearly stated that non-accessibility and difficulty in operating the handle of Gun Control Equipment during operation. Sighting system and seat of existing tank has poor ergonomic design. Hand grip strength gradually decreases with increasing operation time.

Key words: Ergonomics analysis; Combat Vehicle; Gunner seat and sighting system; biomechanical response; musculoskeletal discomfort; Tank -T90,

\section{Access this article online}

Website:

http://nepjol.info/index.php/AJMS DOI: 10.3126/ajms.v12i1.30419

E-ISSN: 2091-0576

P-ISSN: 2467-9100

Copyright (c) 2021 Asian Journal of Medical Sciences

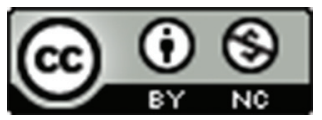

This work is licensed under a Creative Commons Attribution-NonCommercial 4.0 International License.

\section{INTRODUCTION}

A combat vehicle ${ }^{1}$ is tracked/wheeled land or amphibious vehicle, with or without armour or armament, designed for specific functions in combat or battle. It is an integrated mobile weapon platform comprising of multiple workstations having many instruments, equipment, switches, displays etc. Space constraints and multitasking 
of crew during their operation necessitate the ergonomic layout of this equipment. The environment inside a combat vehicle is a kin to a workplace with dynamically changing physiological and psychological conditions. Survivability of crew in operation makes these workstations more challenging and injury prone. Training and comfort of the man behind is important for optimal utilization of the machine. Contemporary literature contains papers focusing on office, industrial and automotive seating because of the economic costs associated with discomfort and injury. ${ }^{2-5}$ Combat wheeled/tracked vehicle fleet includes Armoured Combat Vehicles (ACVs) and Integrated Combat Vehicles (ICVs) of different variant. They are Tank T-55, variants of T-72, T-80UD, T-90S, Main Battle Tank (MBT) Arjun, Leopard I \&II, Abraham M1A1 \& M1A2 and variants of Armoured Personnel Carrier (APC). Design of combat tracked vehicle is based on physical limits, operational limits, maintenance doctrine and human factors. ${ }^{1}$ In American/European concept, a platform is built keeping human at the centre of the design and development, whereas in Russian concept first a platform is built and then it is required to fit the men inside. The T-series ${ }^{6}$ tanks are of Russian origin whereas combat vehicle MBT Arjun, M1A1 Abraham, Leopard I \&II etc. are of nonRussian origin.

These Tanks have two / three/ four men crew. Each crew has his own work space in the vehicle to perform their respective tasks which can be termed as workstations. Location and siting of each of these gadgets, instruments and displays are very important. Nomenclature of crews as per their role $\operatorname{are}^{1,7}$

(a) Driver(Dvr) - Driving and manoeuvring of vehicle

(b) Gunner(Gnr) - Target acquisition and firing of main gun.

(c) Loader(Ldr) - Stacking and loading of ammunition into main gun.

(d) Commander(Cdr) - Overall Command Control, Coordination between the crews, Target acquisition, Override the Gunner for firing, etc.

In Tank T- 90s, gunner station plays an important role on tasking and performance of Gunner and on his action inside the combat vehicle as per tactical scenario and operational requirement. The gunner seat is mounted on the rotary conveyor. Gunner seat can be adjusted in height and along longitudinal axis of the tank on permanent basis by fixing three mounting nuts matching the hole cut in seat bracket and its basic structure. Gunner workstation is stationed in the left half of fighting compartment, separated by the main gun (Gun system $2 \mathrm{~A} 46 \mathrm{M})^{8}$ barrel and breech block mechanism from the right half. On the right side is the commander station. These stations have a number of instruments, displays and switches placed within the limited space inside the tank. The tasking of tank crew under the operational condition increases work load and results in early onset of fatigue. Williams et al.(1968) stated the basic principles of placement of components within tank, according to which the important components to be placed first then frequently used components in convenient locations followed by grouping of components according to their functions and arrange the components according to their sequences/ patterns.

Advancement in technology can help to stretch the upper limit of the man's capabilities thereby improving his efficiency and capability during combat operations. Ergonomics approach makes a design more successful for user's acceptance and reduces the potential for ill health at work, such as aches and pains of the wrists, shoulders, neck and back and increases chances of work-related musculoskeletal disorders (WMSDs). Within a tank, the crew has to organize the workplace to keep twists, turns and uncomfortable movements to an absolute minimum and keep sufficient space around self. ${ }^{4}$ Seat of the workplace should be comfortable i.e. one where he/she feels relaxed and doesn't feel pain, heat, cold etc. ${ }^{5,10}$ Till date ergonomics studies on combat vehicles and tanks are limited and less reported globally. ${ }^{2,4,5,11}$ Hence, the present study was undertaken to investigate the gunner station of the combat vehicle (Tank T90 S) with special reference to seat and sighting system in consideration of anthropometric dimensions of the crew members, to find out constraints, design limitations and mismatch in the existing vehicles; and the biomechanical responses (force and angles), comfort and discomfort during the vehicle operation.

\section{MATERIALS AND METHODS}

Ninety (90) healthy male gunner crew member with mean age $35.2 \pm 8.5$ years, height $172.6 \pm 7.5 \mathrm{~cm}$ and weight $72.4 \pm 7.2 \mathrm{~kg}$ volunteered for the present study. Crew consent was obtained with respect to confidentiality. Detailed anthropometric data of gunner crews were collected using standard ergo measuring tape, digital Vernier Caliper and digital weighing machine.

Gunner seat dimension have been measured using standard ergo measuring tape and Vernier Caliper. The data recorded included dimensions of the seatbase, lumber support and its height from mounting (Rotary Conveyor).

Gun sighting system 1G46 is used for target recognition, acquisition and destruction. Visual display of thermal camera shows the thermal image of the target. Height of eye piece of the sight and visual display were measured 
using standard measuring ergo tape. Angle of neck for viewing eye piece of $1 \mathrm{G} 46$ and periscopes were measured with the help of Goniometer.

Gunner sight (Sight 1G46) has two degrees of freedom for movement and different force is required on each axis. Left-hand handle of the control unit has range finding push button and right-hand handle has Gun firing push button. ${ }^{8}$ Crew were instructed to operate the gun laying control handle of 1G46 for 45 minutes and grip strength were measured every two minutes interval. Hand Grip strength of crew was measured with the help of mechanical gripper dynamometer (M/s Sammons Preston, INC. Bolinbrook, IL 60440-4989). Force required to perform various tasks was calculated with the help of standard digital dynamometer. Data was collected in actual ambient environment within the tank with all hatches under closed conditions.

Goniometer was used to measure angles at different parts of the body during the operation of different controls. Photographic method was used to measure the angular travel of the joystick along the thumb line. Angles between different parts of body in sitting postures were observed during operation and at rest.

Vernier Calipers and standard ergo measuring tape were used to measure space between the seat and various instruments located at the gunner station. The horizontal $(\mathrm{H})$ and vertical (V) distance was measured from the centre of the gunner seat keeping the seat at lowest possible position as adjusted. The seat is located $15 \mathrm{~cm}$ above the Rotary Conveyor platform. The horizontal distance measured is the shortest distance of any instrument from the front edge of the seat base. Comfort and discomfort survey was done through subjective analysis using a questionnaire ${ }^{12}$ to highlight the relationship of pain and discomfort to work posture. The responses were rated on 0 to 10 point scale, with ' 0 ' for no discomfort to ' 10 ' for severe discomfort. All the statistical analysis were conducted using version 17 of Minitab. $\mathrm{p}<$ 0.05 was considered as the level of significance.

\section{RESULTS}

Anthropometric dimensions of crew members were measured to compare the free space required and that available at the gunner station. Mean and standard deviation of each parameter has been calculated to compare the existing space are presented in Table 1.

Dimension of the gunner seat is $34 \times 30 \mathrm{~cm}$. The backrest has dimension $34 \times 15 \mathrm{~cm}$ and is located $15 \mathrm{~cm}$ above seat base and $7 \mathrm{~cm}$ behind, which is secured on a bracket welded on the iron shaft frame having a tilt of $10^{\circ}$ rearward.

\begin{tabular}{llccc}
$\begin{array}{l}\text { Table 1: Anthropometric parameters of studied } \\
\text { crew members (n=90) }\end{array}$ & Mean (SD) & $\begin{array}{c}\text { Max } \\
\text { (cm) }\end{array}$ & $\begin{array}{c}\text { Min } \\
\text { (cm) }\end{array}$ \\
\hline S No & Parameters (cm) & & 41 & 37 \\
& & $39.6(1.67)$ & 56 & 52 \\
\hline 1 & Acromial Breadth & $54.2(1.64)$ & 40 & 36 \\
2 & Acromion Height(seating) & $38.5(1.5)$ & 53 & 47 \\
3 & Bicristal breadth & $53.2(4.49)$ & 58 & 39 \\
4 & Buttock Knee Length & $45.4(4.34)$ & 51 & 39 \\
5 & buttock poplitial length & $63.4(1.52)$ & 65 & 62 \\
6 & Cervicale Height & $82.4(4.16)$ & 87 & 76 \\
7 & Erect sitting height & $70.8(2.24)$ & 74 & 68 \\
8 & Eye Height(seating) & $71(2.24)$ & 74 & 68 \\
9 & Forearm-hand length & $50.8(6.53)$ & 57 & 42 \\
10 & Knee height seating & $36.6(0.89)$ & 38 & 36 \\
11 & Max hip breadth(seating) & $44.8(3.35)$ & 49 & 41 \\
12 & Popliteal height & $29.4(3.05)$ & 33 & 26 \\
13 & Radiale-stylion length & $10.8(0.84)$ & 12 & 10 \\
14 & Tragion-Top of head & & & \\
\hline
\end{tabular}

Gunner seat and back rest are made up of iron sheet as base with jute fibre as cushion stuffed inside canvas clothing fitted onto iron base. Iron base of the seat is bolted to the seat frame which is welded on the rotary conveyor. In Table 2, angular / kinematic changes measured at various operational joints of body during operations are presented.

Sighting system of gunner station includes eye piece of sight 1G46 and Visual display unit (VDU) of thermal camera (TI ESSA). Apart from these there are two periscopic sights (THp-165A) located on the turret roof to observe the front and left side of the tank for any approaching enemy. To see through the periscope sight the gunner has to look by moving his neck upward through an angle up to $50^{\circ}$. VDU is separated laterally by $25 \mathrm{~cm}$ for which gunner has to move his neck by $35^{\circ}$ right to view the screen at the same level.

Forces required for different operations have been analysed vis-a-vis the least measured gripping force capacity of all volunteers for the corresponding operation and the data is presented in Table 3.

Discomfort survey was done via subjective analysis of comfort level of crew on a scale of 0 to10 with ' 0 ' for no discomfort to ' 10 ' for severe discomfort. Mean scales for all points have been tabulated in Table 4 .

Tank T-90S has two types of turret. One is cast turret which is round and dome shaped and the other is the welded turret which is made by welding the armour plate after casting. Due to welding, the space in the welding turret has been increased by giving protruding and disruptive shape at the top of the turret resulting in increase in volume inside the tank by 135 litres to that of cast turret. ${ }^{6}$ According to calculation; one crew member needs an interior space of 1.0-1.7 cubic metre. ${ }^{7}$ 


\begin{tabular}{|c|c|c|c|c|}
\hline S.No & Body location & $\begin{array}{c}\text { Comfortable position } \\
\text { angle }^{13}\left(\text { (in }^{\circ}\right)\end{array}$ & Angle measured $\left(\mathrm{in}^{\circ}\right)$ in rest (range) & $\begin{array}{c}\text { Angle measured (in }{ }^{\circ} \text { ) } \\
\text { during operation (range) }\end{array}$ \\
\hline 1 & Neck & $0-30$ & $0-21$ & $21-45$ \\
\hline 2 & Trunk & $0-30$ & $11-21$ & $21-32$ \\
\hline 3 & Hip & $90-120$ & $93-114$ & $75-86$ \\
\hline 4 & Knee & $90-120$ & $121-132$ & $59-70$ \\
\hline 5 & Ankle & $100-120$ & $107-112$ & 103-107 \\
\hline 6 & Elbow & horizontal/120 & 122 & $70-86$ \\
\hline 7 & Viewing angle & 10-30below the line of sight & above $5^{\circ}$ to below $25^{\circ}$ the line of sight & \\
\hline
\end{tabular}

\begin{tabular}{lcccc} 
Table 3: Force required for different operations & \\
\hline Nomenclature & Initial Force (Kgf) & Force (Kgf) & $\begin{array}{c}\text { Least gripping capacity of crew (Kgf) } \\
\text { \% Capacity } \\
\text { utilised }\end{array}$ \\
\hline (H) Sight 1G46 control handle & 7.153 & 5.115 & 28 & $25.55 \%$ \\
(V) Sight 1G46 control handle & 6.432 & 4.932 & 30 & $21.44 \%$ \\
Gun Elevating Mechanism & 4.025 & 2.015 & 20 & $20.13 \%$ \\
Turret traversing Mechanism & 4.110 & 2.165 & 34 & $12.09 \%$ \\
Turret Lock & 15.785 & 1.272 & 22 & $71.75 \%$ \\
Hatch Opening Mechanism & 9.435 & 1.246 & 32 & $29.48 \%$ \\
\hline
\end{tabular}

\begin{tabular}{llcclc}
\multicolumn{6}{l}{ Table 4: Observed score of discomfort survey } \\
\hline S No & Body Part & Mean & S No & Body Part & Mean \\
\hline 1 & Head & 8.2 & 18 & Neck & 7.9 \\
2 & Left shoulder & 6.75 & 19 & Right Shoulder & 6.8 \\
3 & Left Trapezius & 7.4 & 20 & Right Trapezius & 7.6 \\
4 & Chest & 8.3 & 21 & Thoracic & 6.95 \\
5 & Left Upper Arm & 7.4 & 22 & Right Upper Arm & 6.55 \\
6 & Left Elbow & 6.25 & 23 & Right Elbow & 6.8 \\
7 & Left Forearm & 7 & 24 & Right Forearm & 7.65 \\
8 & Left Wrist & 7.35 & 25 & Right Wrist & 7.2 \\
9 & Left Hand & 6.35 & 26 & Right Hand & 6.9 \\
10 & Abdomen & 8.05 & 27 & Lumber & 6.3 \\
11 & Left Erector Sp. & 8.25 & 28 & Right Erector Sp. & 6.85 \\
12 & Left Gluretus & 8.1 & 29 & Right Gluretus & 7.5 \\
13 & Left Hip & 6.9 & 30 & Right Hip & 7.15 \\
14 & Left Thigh & 6.3 & 31 & Right Thigh & 7.3 \\
15 & Left Knees & 6.4 & 32 & Right Knees & 7.8 \\
16 & Left lower Leg & 6.65 & 33 & Right lower Leg & 7.95 \\
17 & Left Foot & 6.7 & 34 & Right Foot & 7.2 \\
\hline \multicolumn{7}{c}{} & & & &
\end{tabular}

Figure 1. Explains the existing clearances (distances in $\mathrm{cm}$ ) at gunner station between the gunner seat and switches, buttons, instruments and displays at gunner station seat adjusted to rear most position. Horizontal and vertical distance of the instruments and displays are the space for free movement of the operator.

\section{DISCUSSION}

The present study was undertaken to analyze gunner station with special reference to seat, sighting system, in relations to anthropometric dimensions of the crew members to find out constraints and design limitation in the existing vehicles; and biomechanical responses (force and angles), comfort and discomfort during the operation. Observations of the present study revealed that hip of crew is hanging on side beyond the seat as average hip breadth of crew is $36.6 \mathrm{~cm}$ and the seat breadth is $34 \mathrm{~cm}$. This reduces the area of contact and increases the pressure on hip bones. Larger area of contact means lower peak and average pressure., ${ }^{214}$ This indicates that the forces on the thighs, buttocks, and back are spread out over a larger area, thereby decreasing the pressure felt by those tissues. Pressure mapping has been the most highly correlated measuring tool for assessing comfort. ${ }^{2,15}$ Also the comfort and peak pressure depends upon construction material of the cushion. Seat cushion in tank is made up of jute and canvas for durability purpose, however it makes seat surface hard and flat.

Seat has no hand rest making it more tiring and difficult for operation. The posture of holding of the gun handle without hand rest makes it more stressful during the operation. Seat has back support only for $23.6 \%$ of average cervical height $(63.4 \mathrm{~cm})$ and does not provide enough lumbar support thereby resulting in extra load on vertebral column and exerting pressure on shoulder and hip joints which was supported by subjective observation. By using a mathematical model of the adult human hip in the static one-legged stance position of the body; the forces acting on the hip, peak stress in the hip joint and other relevant radiographic and biomechanical parameters were assessed. ${ }^{16}$ Ideally, seat height should be adjustable to support a knee angle of $90^{\circ}$ to $120^{\circ}$. Average knee height $(50.8 \mathrm{~cm})$ and buttock popliteal height $(45.4 \mathrm{~cm})$ leads to very awkward position with knee angle ranging from $72^{\circ}$ to $86^{\circ}$ during operation and from $93^{\circ}$ to $114^{\circ}$ in rest. Low knee angle during operation leads to leg swelling and numbness in thigh muscles (quadriceps and hamstring) due to increased pressure. Being a low seat it increases pressure on 
ischialtuberosities (seat bones). ${ }^{17}$ Gunner sits in awkward position during operation, having angle at waist below $90^{\circ}$ whereas hip angle should be $90^{\circ}-120^{\circ} .{ }^{9,13}$ Detailed analysis of gunner seat is provided in Table 5 .

The control handle operates from $40^{\circ}$ faraway to $25^{\circ}$ towards the gunner and during operation the position of the hand grip becomes uncomfortable. The awkward elbow angle and location of gun handle above elbow height increases undue stress at elbow and shoulders of body which may increase the risk of early fatigue during operation. It can be seen in the (Photo plates 1-4) that stretched and contracted angle of wrist (flexion and extension) in vertical plane during operation produces more strain on the forearm and difficult to operate continuously. This has an effect on the hand grip strength which is explained in the Figure 2 and shows conformity with earlier studies ${ }^{18}$.

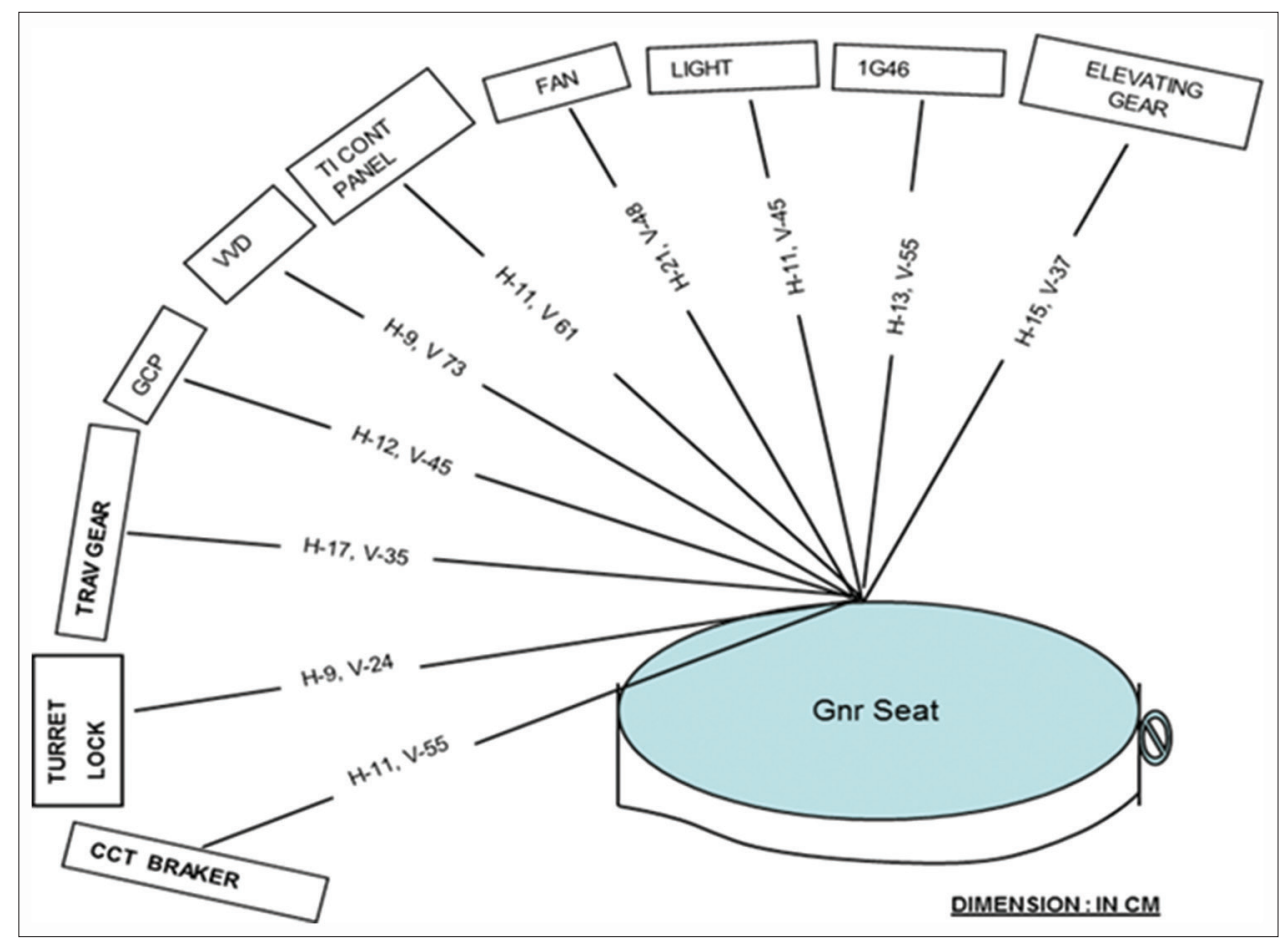

Figure 1: Gunner station: welded and cast turret

\begin{tabular}{|c|c|c|c|c|c|}
\hline \multirow{2}{*}{$\begin{array}{l}\text { Anthropometric } \\
\text { Parameter }\end{array}$} & \multicolumn{2}{|c|}{ Measurement } & \multirow[t]{2}{*}{ Desired } & \multirow[t]{2}{*}{ Mismatch } & \multirow[t]{2}{*}{ Analysis/ Impact } \\
\hline & $\begin{array}{l}\text { Existing Seat } \\
\text { Dimension }\end{array}$ & $\begin{array}{l}\text { Crew Average } \\
\text { Dimension }\end{array}$ & & & \\
\hline Seat Height & $15 \mathrm{~cm}$ & $44.8 \mathrm{~cm} \mathrm{(3.35)}$ & (=poplitial height) & (<<poplitial height) & $\begin{array}{l}\text { Increases pressure on back } \\
\text { and hip bone and pressure } \\
\text { on abdomen }\end{array}$ \\
\hline Seat breadth & $34 \mathrm{~cm}$ & $38.5 \mathrm{~cm}(1.5)$ & ( $\geq$ min hip breadth) & (< min hip breadth) & Not sufficient hip support \\
\hline $\begin{array}{l}\text { Seat Length/ } \\
\text { Depth }\end{array}$ & $30 \mathrm{~cm}$ & $45.4 \mathrm{~cm}(4.34)$ & $\begin{array}{l}\text { Slightly } \leq \text { buttock } \\
\text { poplitial length }\end{array}$ & $<<$ buttock poplitial length & $\begin{array}{l}\text { Hanging thigh- numbness in } \\
\text { thigh \& lower leg }\end{array}$ \\
\hline Back Support & $34 \times 15 \mathrm{~cm}$ & $\begin{array}{l}34 \times 63.4 \mathrm{~cm} \\
\quad(1.52)\end{array}$ & $\begin{array}{l}\text { enough to support } \\
\text { lumbar and cervical }\end{array}$ & only $23.6 \%$ of avg cervical length & $\begin{array}{l}\text { Less lumber support } \\
\text { aggravating shear force on } \\
\text { back bone }\end{array}$ \\
\hline Cushion & No & - & $\begin{array}{l}\text { should be able to } \\
\text { distribute the upper } \\
\text { body weight }\end{array}$ & Iron base with jute cover & Extra Pressure on seat bone \\
\hline Frame & Fixed & - & suspended/ floating & Fixed on rod & $\begin{array}{l}\text { Vehicular shock/ vibration } \\
\text { directly passed to body }\end{array}$ \\
\hline Frame Anchor & $\begin{array}{l}\text { Iron Rod } \\
\text { fixed on nut }\end{array}$ & - & adjustable & $\begin{array}{l}\text { Two fixed position along the } \\
\text { vehicular length and vertical plane }\end{array}$ & $\begin{array}{l}\text { Seat height fixed at two } \\
\text { position }\end{array}$ \\
\hline Head Rest & No & - & desired & Not Available & $\begin{array}{l}\text { increase in weight on neck, } \\
\text { Stress on trapezius }\end{array}$ \\
\hline
\end{tabular}


In Gunner station, gun sighting handles are located below the recommended optimum vortex angle of $\pm 15^{\circ}$ from normal line of sight in vertical and horizontal plane. ${ }^{11,19}$. The eye piece and Visual Display Unit (VDU) of thermal camera lies within the vortex angle, at a height of $58 \mathrm{cms}$, whereas the average height of eye of gunners in sitting position is $71 \mathrm{cms}$ in vertical plane. They are separated by

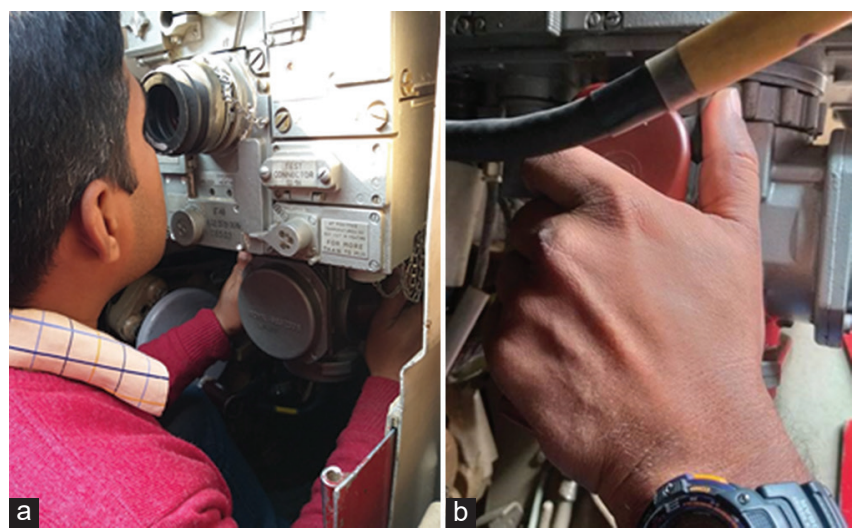

Photo Plate 1 and 2: (a and b) Wrist at neutral position

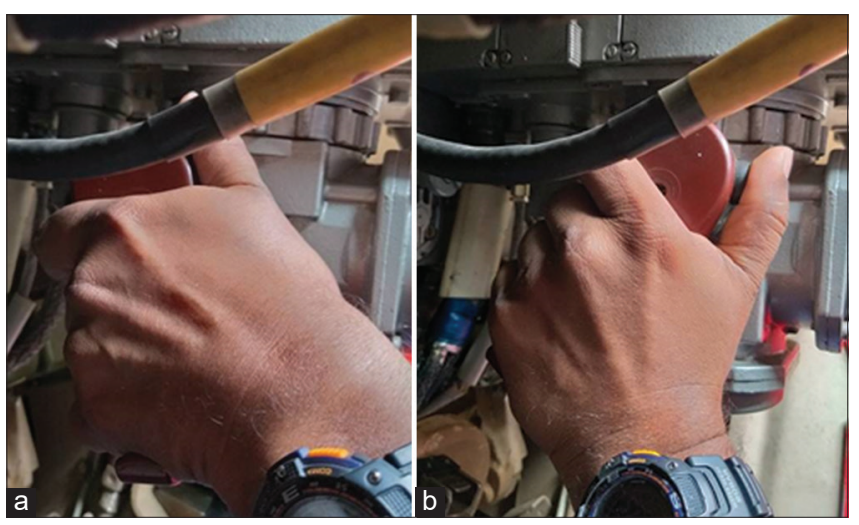

Photo Plate 3 and 4: ( $a$ and b) Deviation of wrist position during operation of gun handle
$25 \mathrm{cms}$, requiring a neck movement of $35^{\circ}$ whereas the neck angle should not exceed $20^{\circ}-30^{\circ 20}$. These movements provide higher pressure on the neck and shoulder muscles. Two periscope sights are separated by more than $90^{\circ}$, and to use them, the gunner has to bend his neck rearward by an angle of $50^{\circ}$ and then look upward and for the lateral periscope the gunner has to rotate his neck by $90^{\circ}$ (Photo plate 5-7). All these movements put excessive stress on the neck region and strain on vertebrae and shoulder thereby causing extra strain and increase the risk of early fatigue to neck and shoulder muscles. Longer use can lead to fatigue, pain and symptoms of WMSDs (Work-related musculoskeletal Syndrome Disorder). These movements can be reduced by screen sharing input of these sights on the improvised VDU.

Force analysis (Figure 2) of crew's hand gripping capacity to operate $1 \mathrm{G} 46$ indicates that the capacity of the hand grip initially increases and then decreases slowly due to continuous operation of the control handle of 1G46 sight. Force required is different for single and double handed operation. The trend line in the graph shows strong correlation of hand grip strengths with time for both hand, left hand $\left(\mathrm{r}=0.809, \mathrm{R}^{2}=0.6547, \mathrm{p}<0.05\right)$ and right hand $\left(r=0.862, \mathrm{R}^{2}=0.7425, \mathrm{p}<0.05\right)$ for the duration of operation. This observation of the present study extended the findings of earlier studies. ${ }^{18}$ Reduction of the force strength is due to awkward position and strained movement of hand and grip as indicated in the Photo plate 01-04. Similar relations have been achieved in earlier study of muscle vs fatigue where the force declines with increase in the time of operation. This is due to the co-contraction factor. ${ }^{17}$

Reduction in gripping capacity of the gunner might compromise the swiftness of the gunner and may produce lag and delay in movement of barrel. Input to the gun

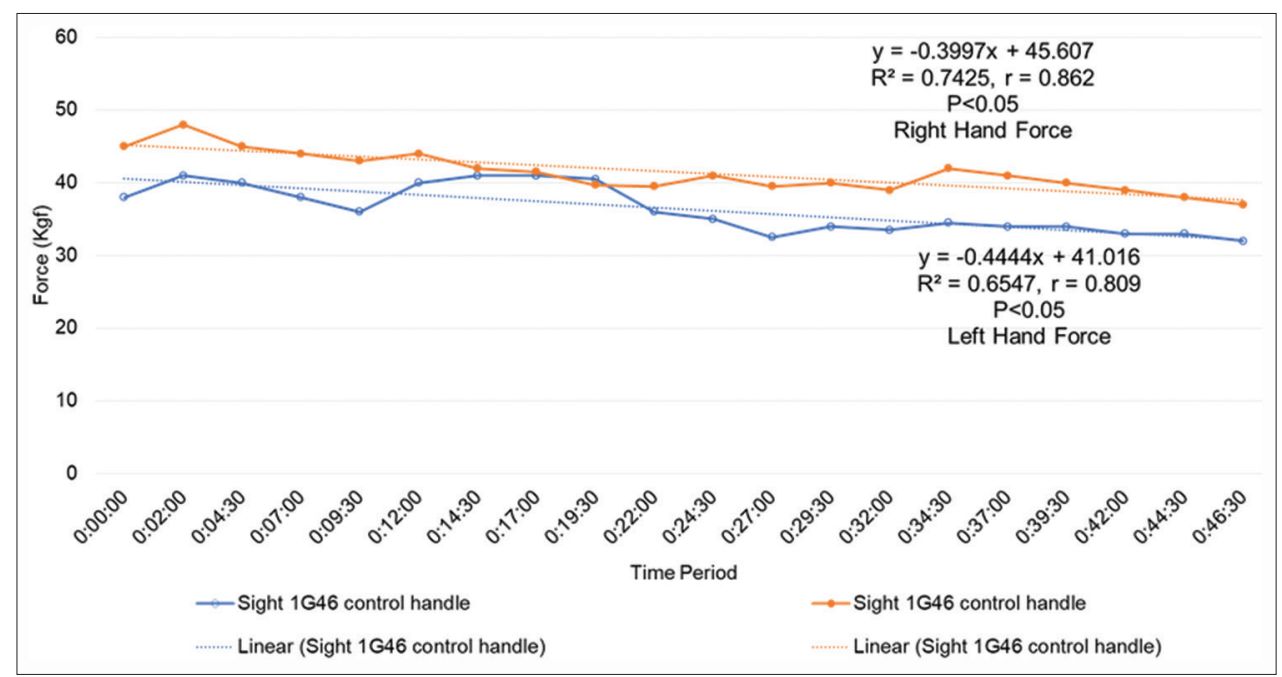

Figure 2: Hand grip strength analysis of gunner during operation of different controls 


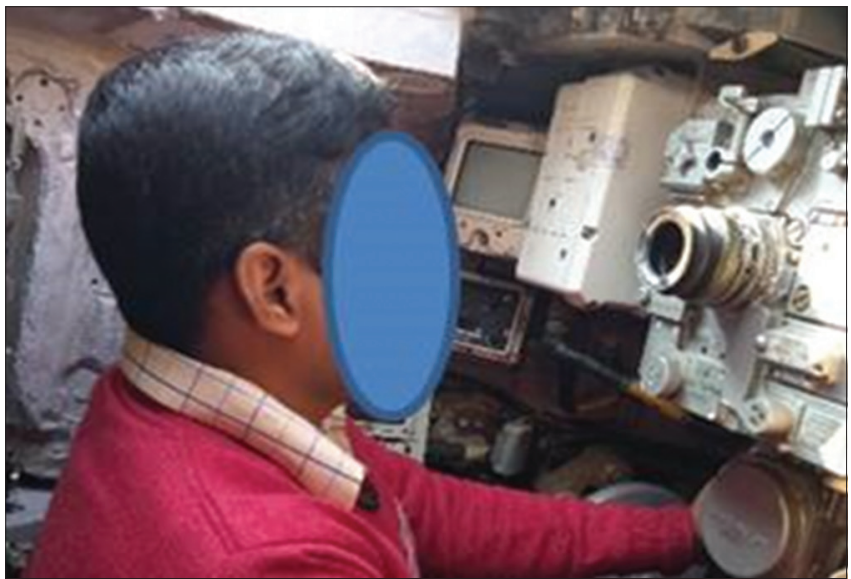

Photo Plate 5: Neck at neutral position

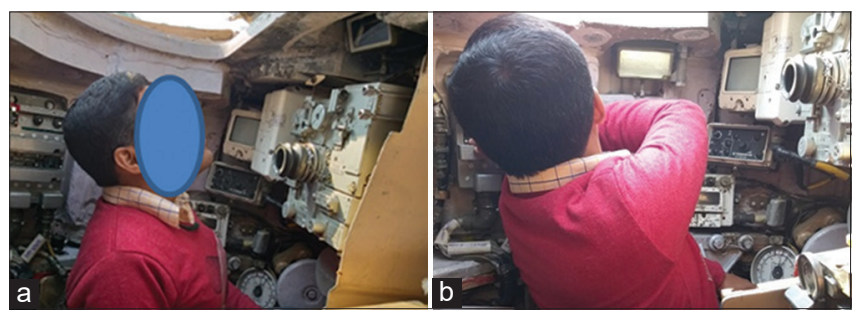

Photo Plate 6 and 7: ( $a$ and b) Neck position during view through periscope

control unit can be improvised by replacing existing control handle with joystick box connected with flexible cable. As seen in Figure 1, free space available at gunner station varies from 04 to $21 \mathrm{~cm}$ from the seat, whereas average Radialestylon length of crew is 29.4 (3.05) cm indicating no space for free movement (row 13 of Table1). Instruments and equipment have been arranged to avoid repetitive tasking. ${ }^{21}$

Earlier studies reported that inappropriate height of backrest, seat to ground height, and seat width were responsible for development of lordosis and musculoskeletal discomfort or disorders. Work in inappropriate working posture/workstations causes a higher rate of worker complaints of undue strain, localised fatigue, discomfort, or pain that does not go away after rest. ${ }^{17,22}$ Observations of the present study by discomfort analysis extended the findings of earlier studies. Present study stated that mean score of analysis discomfort was higher in upper part of the body i.e. chest (8.3), Left erector muscle (8.25), head (8.2), abdomen (8.05), neck area (7.9) as mentioned in Table 4 . Discomfort in right part of the lower body was more due to space constraint because of gunner protection plate (Photo plate 1). In upper body it is less on the right part because of support of the same plate and no support on left part. These effects are in conformity to analysis of discomfort survey. Tank T 90-S Gunner station design parameters should be modified to reduce discomfort and enhance efficiency of the Gunner.

\section{CONCLUSION}

Observation of the present study clearly indicates that there's difficulty in operating the handle of Gun Control Equipment. Operation of sighting systems causes excessive strain on neck and shoulder muscles due to awkward postures during operations. Seat of existing tank is also not ergonomically designed as per anthropometric dimension of crew members. Detailed ergonomics studies on crew compartment of T90 Tank are required to highlight the mismatch and flaw in ergonomics design so that operational readiness of crew members is maintained and optimally utilised.

\section{ACKNOWLEDGEMENTS}

The author is grateful to Indian Army for allowing study on its crew and equipment, Vice Chancellor, DIAT, Girinagar, Pune for providing opportunity to interact with DIPAS, Delhi. The author would like to thanks Director, DIPAS for allowing Dr Madhusudan Pal as co-guide and utilization of facilities and equipment. The authors would like to thank Prof S Das for extending his help and support during the course of work.

\section{REFERENCES}

1. NTIS. Engineering Design Hand Book. Automotive series. The automotive assembly, headquarters, US Army Material Command, AD830268, 1965, 3: 18-21 and 25-29,4:1-2.

2. Openshaw S D. Predicting and quantifying seated comfort and discomfort using objective and subjective measures; PhD (Doctor of Philosophy) thesis. University of lowa. 2011.

3. Henriksen $\mathrm{K}$ and Albolino S. Towards a safer healthcare system. Qual Saf Health Care. 2010; 19(Suppl 3):i1ei2. https://doi.org/10.1136/qshc.2010.045849

4. MAO M, Fang XIE, Jian-jun HU and Bo SU. Analysis of Workload of Tank Crew under the condition of information; Defence Technology. 2014; 10:17-21.

https://doi.org/10.1016/j.dt.2013.12.008

5. Macuzaic $S$ and Lukic J. Ergonomics analysis of automobile seat comfort. Infoteh-Jahorna Mar 2017; 16. University of Kragujevac. Faculty of engineering 34000 Kragujevac, Serbia.

6. Mannual. Tank T-90S Technical Description Part I and II (Album of Illustration 188.TO-э5). Russia, page no 50.

7. USACAE. Mil_std_1472F Human Engineering and Design Criteria Standard by USA Command for Automotive Engineering. Tank. 23 Aug 1999.

8. Manual. Tank T-90S Operating Instruction (188.ѝэ - э5). Russia,72-88.

9. https://en.wikipedia.org/wiki/Human_factors_and_ergonomics.

10. Chandra. P, Ananth G, Vinod B and Gowtham PVS. Analysis for response Factors of a work station considering Issues Ergonomically; IOSR Journal of Mechanical and civil Engineering. 2015; 12(6iii): 37-60.

11. Malhari A, Bhattacharyya D, Arya K, Chatterjee $T$ and Pal M. Assessment of vibration exposure and physiological responses 
of crew members during Infantry Combat Vehicle (ICV) operation: a pilot study. J R Army Med Corps. 2018; 0:1-7. https://doi.org/10.1136/jramc-2018-001022

12. Corlett EN and Bishop RP. A Technique for assessing postural discomfort. Ergonomics. 1976; 19 (2): 175-182.

https://doi.org/10.1080/00140137608931530

13. https://www.ccohs.ca/oshanswers/ergonomics/sitting/sitting_ position.html.

14. De Looze Michiel P, Kuijt-Evers Lottie F M and Dieen Jaap Van. Sitting comfort and discomfort and relationships with objective measures. Ergonomics. 2003; 46(10): 985-997. https://doi.org/10.1080/0014013031000121977

15. Michael N Sawka and Scott J Montain. Fluid and electrolyte supplementation for exercise heat stress. The American Journal of Clinical Nutrition. 2000; 72 (2):564S-572S.

https://doi.org/10.1093/ajcn/72.2.564S

16. Mavcic B, Pompe B, Antolic V, Daniel M, Iglic A and Kralj-Iglic V. Mathematical estimation of stress distribution in normal and dysplastic human hips. Journal of Orthopaedic Research. 2002; $20: 1025-1030$.

https://doi.org/10.1016/S0736-0266(02)00014-1
17. Peng J, Xuguang $\mathrm{W}$ and Lias $\mathrm{D}$. Ranges of the least uncomfortable joint angles for assessing automotive driving posture. Applied Ergonomics. 2017; 61:12-21. https://doi.org/10.1016/j.apergo.2016.12.021

18. Shorten Paul R, O'Callaghan Paul, Davidson John B and Sooleva Tanya K. A mathematical model of fatigue in skeletal muscle force contraction. J Muscle Cell Motil. 2007; 28(6):293-313. https://doi.org/10.1007/s10974-007-9125-6

19. Swann M. Ergonomic requirements for office work with visual display terminals(VDTs). ergonomic Solution; ISO 9241-5.1999-summary.2-3.

20. DEA $3250 / 6510$ Class notes. Sitting and Chair Design. Cornell university web; http://ergo.human.cornell.edu/dea3250flipbook/ dea3250notes/sitting.html.I

21. Ravindra and Goonetilleke. Advances in Physical Ergonomics and Human Factors;. Proceedings of the AHFE 2016 International Conference on Physical Ergonomics and Human Factors. July, 27-31. Walt Disney World®. Florida, USA. Springer 2016. https://doi.org/10.1007/978-3-319-41694-6

22. Sepehri S, Habibi $A H$ and Shakerian S. The relationship between ergonomic chair and musculoskeletal disorders in north of Khuzestan students. Eur. J Exp Biol. 2013; 3(4):181-187.

\section{Author's Contribution:}

PKS - Reviewed literature, study designed, data collected, analyzed, interpreted and prepared draft manuscript; MP - Conceptualized, Coordinated for conducting study, reviewed and finalized manuscript; SC - Reviewed literature, interpreted data, critically reviewed draft manuscript and provided inputs.

\section{Work attributed to:}

Ministry of Defence.

Orcid ID:

Dr. Madhusudan Pal - (iD https://orcid.org/0000-0002-9657-5858

Source of funding: None, Conflict of Interest: None. 